\title{
Pressotherapy of a postoperative scar with the application of non-sterile silicone dressings in a 56-year-old woman treated for breast cancer in the Holycross Cancer Centre in Kielce
}

\section{Presoterapia blizny pooperacyjnej z zastosowaniem niejałowych opatrunków silikonowych u 56-letniej pacjentki leczonej z powodu raka piersi w Świętokrzyskim Centrum Onkologii w Kielcach}

\author{
Paweł Macek ${ }^{1,2}$, Małgorzata Terek-Derszniak³, Anna Lipińska, ${ }^{3,4}$ Ewa Błaszkiewicz ${ }^{1,5}$, Halina Król6,7, \\ Stanisław Głuszek ${ }^{8-10}$, Stanisław Góźdźn $z^{11,12}$ \\ 1Department of Cancer Epidemiology and Cancer Control, Holycross Cancer Centre, Kielce, Poland \\ Head of the Department: Teresa Karpacz \\ ${ }^{2}$ Faculty of Medical Sciences, School of Economics, Law, and Medical Sciences, Kielce, Poland \\ Head of the Faculty: Grzegorz Gałuszka PhD \\ ${ }^{3}$ Department of Rehabilitation, Holycross Cancer Centre, Kielce, Poland \\ Head of the Department: Anna Opuchlik PhD \\ ${ }^{4}$ Department of Organ of Hearing and Balance Rehabilitation, Institute of Physiotherapy, Faculty of Medicine and Health Sciences, \\ Jan Kochanowski University, Kielce, Poland \\ Head of the Department: Prof. Stanisław Bień MD, PhD \\ ${ }^{5}$ Department of Education, Jan Kochanowski University, Kielce, Poland \\ Head of the Department: Agnieszka Świerczek MA \\ ${ }^{6}$ Department of Science, Holycross Cancer Centre, Kielce, Poland \\ Head of the Department: Stanisław Góźdź MD, PhD, Prof. JKU \\ ${ }^{7}$ Department of Developmental Age Research, Institute of Public Health, Faculty of Medicine and Health Sciences, \\ Jan Kochanowski University, Kielce, Poland \\ Head of the Institute: Grażyna Nowak-Starz PhD, Prof. JKU \\ ${ }^{8}$ Clinic of General, Oncological and Endocrinological Surgery, Provincial Voivodeship Hospital, Kielce, Poland \\ Head of Clinic: Prof. Stanisław Głuszek MD, PhD \\ ${ }^{9}$ Department of Surgery and Surgical Nursing with a Laboratory for Scientific Research, Institute of Nursing and Obstetrics, \\ Faculty of Medicine and Health Sciences, Jan Kochanowski University, Kielce, Poland \\ Head of Department: Prof. Stanisław Głuszek MD, PhD \\ ${ }^{10} \mathrm{Clinic}$ of Oncological Surgery, Holycross Cancer Centre, Kielce, Poland \\ Head of Clinic: Jacek Haduch MD \\ ${ }^{11}$ Clinic of Clinical Oncology, Holycross Cancer Centre, Kielce, Poland \\ Head of the Clinic: Stanisław Góźdź MD, PhD, Prof. JKU \\ ${ }^{12}$ Department of Cancer Prevention and Epidemiology, Institute of Public Health, Faculty of Medicine and Health Sciences, \\ Jan Kochanowski University, Kielce, Poland \\ Head of the Institute: Grażyna Nowak-Starz PhD, Prof. JKU
}

Key words: pressotherapy, hypertrophic scars, keloid, mastectomy, breast cancer.

Słowa kluczowe: presoterapia, blizny przerostowe, keloid, mastektomia, rak piersi.

\begin{abstract}
Scarring is a natural process of wound healing. In some cases, however, there is formation of hypertrophic scars and keloids that are the result of collagen decomposition and synthesis. A disturbed scarring process causes functional, aesthetic, and psychological disorders in the patient. Silicone dressings in the form of plasters or gel are used in the treatment of hypertrophic scars and keloids. A case of pressotherapy of a postoperative scar with the use of non-sterile silicone dressings in a 56-year-old patient treated for breast cancer is described herein. The use of a 2-month pressotherapy of the scar resulted in an improvement in all the assessed parameters. Pressotherapy of the postoperative scar in the patient after mastectomy proved to be an effective and promising method. However, the methods of the scar assessment before and after treatment need objectivity.
\end{abstract}




\section{Streszczenie}

Blizna jest efektem naturalnego procesu gojenia się ran. W niektórych przypadkach dochodzi jednak do tworzenia się blizn przerostowych i keloidów, które są wynikiem zaburzenia rozkładu i syntezy kolagenu. Nieprawidłowy proces bliznowacenia powoduje u pacjenta zaburzenia czynnościowe, estetyczne i psychologiczne. Blizny przerostowe i keloidy są zazwyczaj zlokalizowane na skórze w obrębie klatki piersiowej, pleców, ramion oraz w miejscach zwiększonego napięcia mięśni. Opatrunki silikonowe w postaci plastrów lub żelu stosuje się w leczeniu blizn przerostowych i keloidów. W badaniach z randomizacją wykazano, że stosowanie opatrunków silikonowych jest skuteczne w poprawie koloru, rozmiaru i twardości blizny. Opisano przypadek presoterapii blizny pooperacyjnej z użyciem niejałowych opatrunków silikonowych u 56-letniej pacjentki leczonej z powodu raka piersi. Zastosowanie 2-miesięcznej presoterapii blizny umożliwiło uzyskanie poprawy w zakresie wszystkich parametrów poddanych ocenie. Presoterapia blizny pooperacyjnej u pacjentki po mastektomii okazała się metodą skuteczną i obiecującą. Zobiektywizowania wymagają natomiast metody oceny blizny przed terapią i po jej zakończeniu.

\section{Introduction}

Scarring is a natural result of wound healing. In some cases, however, there is formation of hypertrophic scars and keloids that are the result of collagen decomposition and synthesis $[1,2]$. The cause of the formation of hypertrophic scars and keloids is not fully known. Some scars heal well, which leads to the formation of an imperceptible thin line, others are susceptible to the hypertrophy of a scar, and in the worst case, to the conversion into a keloid. A disturbed scarring process causes functional, aesthetic, and psychological disorders in the patient $[1,3]$. Frequent symptoms associated with hypertrophic scars and keloids are: itching, pain, and restriction of movement, especially in the vicinity of the joints [4-7]. If left untreated, scars can cause contractures negatively affecting the patient's health [8-10]. Hypertrophic scars and keloids are usually localised on the skin in the area of the chest, back, shoulders, in places of increased tension, and more often on flexor muscles [8].

\section{Case report}

A 56-year-old patient was admitted to the Holycross Cancer Centre in Kielce for the diagnosis of a tumour in the left breast. On the basis of material collected in a thick-needle biopsy performed on 1.02.2012 a triple-negative invasive duct carcinoma of the left breast at grade G2 (G2 ductal carcinoma invasivum mammae, "triple negative") was found. Assessment of oestrogen receptors (ER) and progestogen (PgR) showed ER (1+), PgR (-), HER2 (-).

The patient was qualified for a modified radical mastectomy of the left breast in the Madden way (mastectomia sinistri modo Madden). The amputation of the left breast was performed from a transverse cutaneous cut. During the preparation of the armpit, numerous hard lymph nodes in all the levels of the armpit lymphatic system were found - one node at the top of the armpit, the others along the thoracic-dorsal bundle. The nodes were of different sizes and were hard. They all were removed. The postoperative material was sent for histopathological examination.
As a result of the pathological examination performed on 13.04.2012, a duct carcinoma G3 according to Elston-Ellis was found in the material taken during the surgery (the whole organ). The maximum size of the infiltrating cancer was $43 \mathrm{~mm}$. There was no cancer cell embolism in the lumens of the thinwalled vessels around the tumour $\mathrm{p}$ T2. The receptors were determined in the previous study. Additional pathological data: Nottingham Prognostic Index - 4.8 points, lymph node status - 1 point, histological malignancy grade -3 points, diameter of the infiltrating cancer in $\mathrm{cm} \times 0.2-0.8$ points. Twelve lymph nodes without metastases of cancer $(0 / 12)$ were dissected from the left armpit.

Adjuvant chemotherapy was employed in the patient during the period 14.06.2012-11.10.2012. Six cycles of FEC (78 mg 5-fluorouracil, $110 \mathrm{mg}$ epirubicin, $780 \mathrm{mg}$ cyclophosphamide) were applied. As protection $8 \mathrm{mg}$ Ondansetron and $4 \mathrm{mg}$ Dexamethasoni natrii phosphas were applied.

The patient was admitted to the Department of Radiotherapy in order to have adjuvant radiotherapy during the period 7.01-2.02.2013. The area of irradiation included the chest walls on the left side and the over-and subclavian area in accordance with the treatment plan. A total dose of $45 \mathrm{~Gy}$ in 20 fractions was given.

The patient came to the Department of Rehabilitation on 26.04.2012. The range of motion in the shoulder joint was examined and the following results were found: flexion $-90^{\circ}$, abduction $-90^{\circ}$, and external rotation $-30^{\circ}$. The patient was recommended to learn self-massage of the left upper limb, exercises to relieve the left upper limb, self-adjunct exercise of the upper left limb, individual exercise of the left shoulder joint, massage and mobilisations of the postoperative scar, and a whirlpool massage of the upper left limb.

After the completion of radiotherapy, the patient reported pain in the vicinity of the postoperative scar and restriction of the abduction movement of the left upper limb in the shoulder joint. On physical examination the postoperative scar was plicate, drawn into an intercostal space, and segment immobile. The left armpit was without change. Swelling of the subcuta- 
neous tissue was visible in an ultrasound examination done on 24.05.2013 in the plane of the postoperative scar (Figure 1).

The assessment of the postoperative scar was made on the basis of the Patient and Observer Scar Assessment Scale (POSAS) and Vancouver Scar Scale (VSS). Patient and Observer Scar Assessment Scales included two elements. One element was filled in by the observer, and the other was assessed by the patient. The patient assessed the thickness, flexibility, colour, pain, and itching. The observer assessed the vascularisation, pigmentation, thickness, and mobility. Each element was rated on a scale of 0 to 10 , where 10 meant the worst conceivable scar. On the basis of Vancouver Scar Scale four variables were assessed: vascularisation, height (thickness), flexibility, and discoloration. The scoring range was 0 to 14, where 0 meant normal skin.

Pressotherapy of the postoperative scar with the use of non-sterile silicone dressings was employed for a period of 2 months (from 7.02.2013 to 9.02.2013) after obtaining the doctor's consent. The patient was informed about the objectives, principles, and methods of pressotherapy of the scar, and the potential benefits and risks. A non-sterile silicone dressing was changed once a week. The patient was in the non-sterile silicone dressing all day and night with a 1-hour break for hygienic purposes.

Before starting the pressotherapy, the patient assessed the scar as painful, itchy, irregular, stiff, and of a colour different from the colour of normal skin. She assessed the pain of the scar as 10 on a 10-point scale (POSAS). Itching of the scar was assessed as $8 / 10$. The colour, stiffness, and irregularity of the scar were assessed as being 10/10, and the thickness of the scar as $5 / 10$. The second part of the scar assessment was conducted by the observer. The worst assessment $(10 / 10)$ was obtained for the scar deformability, where 10 meant the worst imaginable scar. The bulge of the scars was rated at $8 / 10$ and thickness at $3 / 10$. The vascularisation was assessed as $3 / 10$ and pigmentation as 2/10.

Then the scar was assessed on the basis of VSS. After the assessment of the vascularisation, pigmentation, deformability, and height, a score of 8 was obtained (on a scale of 0 to 14 , where 0 meant normal skin) (Figure 2).

After 2 months of applying the pressotherapy in the vicinity of the scar, improvement in all the assessed parameters was obtained. Pain, itching, colour, stiffness, and thickness of the scar were assessed by the patient as 1 on a 10-point scale. The irregularity of the scar was assessed by the patient as $2 / 10$. In the part assessed by the observer the greatest improvement was observed in the deformability and bulging of the scar at $2 / 10$. The thickness was assessed as $2 / 10$, and vascularisation and pigmentation as 1 on the 10 -point scale. The result based on the assessment according to

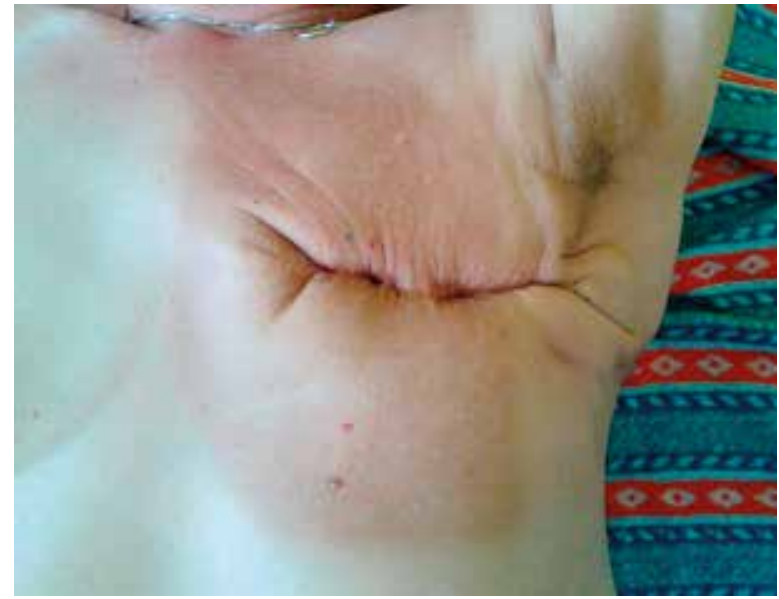

Figure 1. Postsurgical scar before the start of pressotherapy

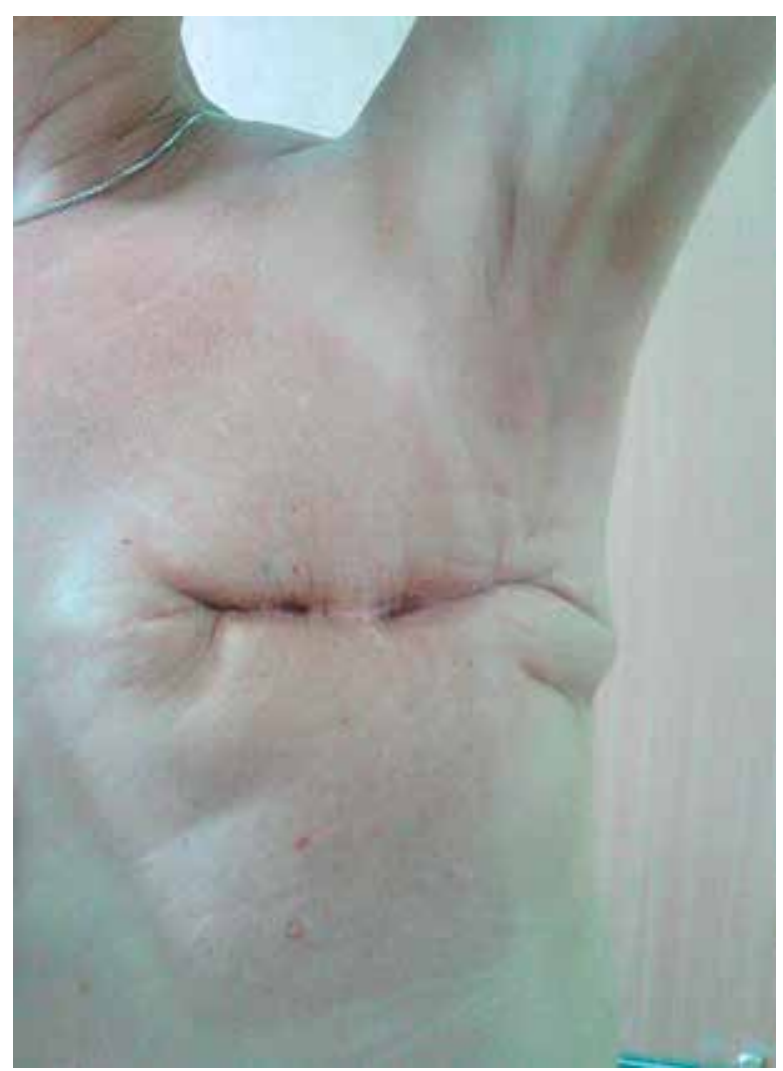

Figure 2. Postsurgical scar after 2 months of pressotherapy

Vancouver Scar Scale was 4, whereas before the pressotherapy it was 8 .

\section{Discussion}

Breast cancer is the most common malignant neoplasm in women. Breast cancer treatment is a combination therapy (surgery, radiotherapy, chemotherapy) and can be the cause of complications and functional 
disorders of the musculoskeletal, respiratory, circulatory, and nervous systems [11-13].

A common complication after mastectomy is extensive fibrillation of the operated area accompanied with the formation of contractures. Keloids can arise in the place of the postsurgical scar, which leads to the slowness or inhibition of the process of the lymphatic vessel regeneration. These changes may lead to the abnormal transport of lymph in the lymphatic system resulting in lymphoedema [12, 14, 15].

In patients after mastectomy, who were treated with radiotherapy, early and late complications of radiation are observed [16]. The most severe change is extensive scarring limiting the mobility of the chest and upper limb on the operated side $[12,17]$.

Treatment of hypertrophic scars and keloids is a serious problem for doctors. Often it is not possible to predict how the wound will heal and it is necessary to make efforts to prevent the development of hypertrophic scars and keloids. The choice of treatment depends on the individual needs of the patient, the clinical assessment of the scar, and the location and time of its creation [1]. Particular attention should be paid to high-risk patients. Patients who previously had problems with abnormal scar formation or who undergo procedures with a high risk of scarring, i.e. breast and chest surgery, are particularly exposed to the occurrence of a hypertrophic scar or keloid [18]. Even the smallest surgery leaves scars. Priorities and treatment goals should be determined in individual therapy (e.g. removing functional deformity, aesthetic improvement, prevention of recurrence after a surgical resection, or elimination of symptoms associated with the change) $[1,18]$. Different methods are applied in the treatment of hypertrophic scars and keloids: surgical, physical, and pharmacological [1, 4, 19].

Silicone dressings in the form of plasters or gel are used in the treatment of hypertrophic scars and keloids $[20,21]$. The use of silicone dressings is recommended as a safe, non-invasive, simple, and effective method of prophylaxis [18, 22-24]. The use of silicone dressings substantially improves the flexibility of old scars as compared to the scars untreated with plasters [1]. Most researchers believe that silicone dressings reduce the activity of the capillaries, reduce congestion, and reduce the production of fibroblasts and collagen, causing flattening of the scar. Randomised studies have shown that the use of silicone dressings is effective in improving the colour, size, and hardness of the scar [24]. Treatment of a patient who has a problem with a scar should be selected on the basis of the scar assessment. Assessment of the scar and the patient's case history are the primary criteria for treatment.

\section{Conclusions}

In the presented case description, an improvement in all the studied parameters of the scar after mas- tectomy was achieved in a patient treated for breast cancer. The used pressotherapy of the postoperative scar proved to be effective and promising. Despite the achieved therapeutic success, the authors are unsatisfied with the applied, although recommended and widely used, methods for the assessment of the scar. This results from a large dose of subjectivity with which the used diagnostic methods were burdened. Although the POSAS is based on the binary nature of the scar assessment (patient and observer), in both cases the individual assessment elements of the measured parameters are burdened, in a natural way, with a lower or higher dose of subjectivity. A similar problem can occur during the application of the VSS. Bearing in mind the positive contact between the therapist and the patient formed during several weeks of therapy, and the connected willingness for effective help to the patient (by the therapist) and effective self-help (by the patient), the accuracy of the applied therapy with the use of subjective scales can be inaccurate. This does not change the fact that pressotherapy itself is a method effective in the treatment of hypertrophic scars and keloids. This is confirmed by extensive experience of specialists treating burns and numerous scientific reports demonstrating the efficacy of the method described and clinically applied by the authors. Clarification is needed in reference to the diagnostic methods, which, on the one hand, should be cheap and convenient to use, and on the other hand, should be sensitive and objective.

\section{Conflict of interest}

The authors declare no conflict of interest.

\section{References}

1. Zieliński T, Witmanowski H, Lewandowicz E, et al. Blizny przerostowe i keloidy. Część II. Zapobieganie i leczenie. Postep Derm Alergol 2008; 25: 116-24.

2. Roguś-Skorupska D. Bliznowce-epidemiologia, etiopatogeneza i leczenie. Nowa Medycyna 2002; 3: 7-11.

3. Zurada MJ, Kriegel D, Davis IC. Topical treatments for hypertrophic scar. J Am Acad Dermatol 2006; 55: 1024-31.

4. Broniarczyk-Dyła G, Urysiak I, Wawrzycka-Kaflik A. Keloidy i blizny przerosłe. Postep Derm Alergol 2006; 23: 234-8.

5. Wolfram D, Tzankov A, Pülzl P, et al. Hypertrophic scars and keloids: a review of their pathophysiology, risk factors, and therapeutic management. Dermatol Surg 2009; 35: 171-81.

6. Ladak A, Tredget EE. Pathophysiology and management of burn scars. Clin Plast Surg 2009; 36: 661-74.

7. Tasmuth T, Smitten K. Pain and other symptoms after different treatment modalities of breast cancer. Ann Oncol 1995; 6: 453-9.

8. Juckett G, Hartman-Adamsn H. Managment of keloids and hypertrophic scars. Am Fam Physican 2009; 80: 253-60.

9. Witamowski H, Lewandowicz E, Zieliński T, et al. Blizny przerostowe i keloidy część I. Patogeneza i patomechanizm powstawania. Postęp Derm Alergol 2008; 25: 107-15. 
10. Gauglitz GG, Korting HC, Pavicic T, et al. Hypertrophic scarring and keloids: pathomechanisms and current and emerging tratment strategies. Mol Med 2011; 17: 113-25.

11. Wożniewski M. Fizjoterapia w onkologii. PZWL, Warsaw 2012.

12. Hansdorfer-Korzon R, Burakowska A. Zmiany w obrębie skóry u pacjentek po mastektomii z powodu raka sutka. Forum Medycyny Rodzinnej 2010; 4: 174-80.

13. Macek P, Terek M, Głuszek SZ, et al. Metody redukcji obrzęku limfatycznego na podstawie piśmiennictwa przegląd systematyczny. Stud Med 2014; 30: 43-7.

14. Krukowska J, Terek M, Macek P, et al. Metody redukcji obrzęku limfatycznego u kobiet po mastektomii. Fizjoterapia 2010; 18: 3-10.

15. Macek P, Stanisławek A, Góźdź S. Obrzęk limfatyczny przegląd literatury. Onkologia i Radioterapia 2010; 4: 24-31.

16. Vincent C, Dębowska R, Eris I. Pielęgnacja skóry po radioterapii. Wspolcz Onkol 2007; 11: 223-6.

17. Nyka W, Sokołowski J. W sprawie przyczyn ograniczenia ruchomości w stawie barkowym po mastektomii. Fizjoterapia 1999; 7 Suppl.: 45-8.

18. Mustoe TA, Cooter RD, Gold MH, et al. International clinical recommendations on scar management. Plast Reconstr Surg 2002; 110: 560-71.

19. Figura B. Leczenie blizn. Świat Farm 2009; 11: 18-9.

20. Gauglitz GG. Management of keloids and hypertrophic scars: current and emerging options. Clin Cosmet Investig Dermatol 2013; 6: 103-14.

21. Berman B, Perez OA, Konda S, et al. A review of the biologic effects, clinical efficacy, and safety of silicone elastomer sheeting for hypertropic and keloid scar treatment and managment. Am Soc Dermatol Surg 2007; 33: 1291303.

22. Katz BE. Silicone gel sheeting in scar therapy. Cutis 1995; 56: 56-7.

23. Fulton J. Silicone gel sheeting for the prevention and managment of evolving hypertrophic and keloids scars. Dermatol Surg 1995; 21: 947-51.

24. Oliviera G, Nunes TA, Magna LA, et al. Silicone vers nonsilicone gel dressing: controlled trial. Dermatol Surg 2001; 27: 721-6.

\section{Address for correspondence:}

Paweł Macek MD, PhD

Department of Cancer Epidemiology and Cancer Control

Holycross Cancer Centre

ul. Artwińskiego 3, Kielce, Poland

Phone: +48603161576

E-mail: pawel.macek@gazeta.pl 